\title{
THE GNSS SYSTEM APPLICATION IN THE LPV-200 LANDING APPROACH PROCEDURE. PART I: APPROACH TO PRACTICAL VERIFICATION
}

\begin{abstract}
Current RNAV GNSS approach procedures are widely used in Europe and worldwide. The development of the GNSS systems as well as the study and control of satellite signals result in the increasing number of approach types with increasingly higher demands and lower operating minimums. LPV-200 is the precision approach with the most stringent requirements, and operational minimums of up to 200ft. For the purposes of Part I of this paper static measurements were performed in order to compare the signal characteristics with ICAO requirements. On the basis of the measurements' results, it can be assumed that, within the analyzed period of time, the GNSS signal at the airport in Dęblin only partially met the requirements set for LPV-200 approaches. The data collected were processed and analyzed using Matlab environment.
\end{abstract}

\section{Keywords:}

LPV-200, GNSS, approach procedures, EPDE, Matlab.

\section{INTRODUCTION}

In 2011, the suspension of air operations due to a very heavy snowfall in the United States caused the cancellation of 20 thousand flights. According to the estimates of Vaughn Cordle of Airline Forecasts LLC, airlines could, therefore, lose more than 600 million dollars [www.news.berkeley.edu]. A new approach 
to the analysis of losses supported by professor Mark Hansen from UC Berkeley and Cynthia Barnhart, professor at MIT's School of Engineering, in an interesting and insightful manner analyzes total losses generated by delayed flights. Estimation of losses takes into account among others: costs incurred by passengers, hidden costs of delays (which are anticipated by airlines), costs incurred by airlines, costs of forced changes in flight schedules due to the runway limitations, impact of delayed and canceled flights on gross domestic product due to, among other things, the relationship between air transport and other industries.

According to a new scheme of estimating losses, in 2007, because of delayed flights, the US government lost 4 billion dollars of the gross national product. Losses incurred by airlines amount to 8.3 billion dollars, and according to studies, passengers had to bear the costs of 16.7 billion dollars. The total cost resulting from delayed and canceled flights was 32.9 billion dollars [www.bloomberg.com]. These are enormous sums of money the minimization of which is the aim not only for carriers, operators, and airspace users, but also for the countries within whose airspaces air operations are conducted. It is possible that the implementation of procedures based on GNSS will allow the execution of more planned operations, because of, among other things, better management of airspace, reduced minimums for certain airports, and shorter approach procedures, which will result in increased airport capacity. This may ultimately help to reduce the losses by up to several billion dollars a year.

Another objective is to make every effort to ensure that each flight will end at the destination airport without any problems. Each of the authorities concerned seeks to maximize the safety of air operations. GNSS-based navigation during the arrival and departure procedures, as well as en-route and terminal navigation can contribute to increased safety. Generation of the information redundancy with regard to the position of the aircraft is also a phenomenon which reduces the risk level.

\section{BASICS OF DETERMINING THE CHARACTERISTICS REQUIRED OF A GNSS APPROACH}

On account of the fact that the GNSS service is in many ways different from the traditional navigation systems, certain standards should be adopted in order to characterize its features, and the possibility of comparison with other currently 
existing systems. In the ILS system the thresholds of the monitors (devices controlling the operation) are standardized, and the self-noise of receivers is very small compared with the magnitude of the measured signals. In SBAS systems, noise of the receivers at times prevent the correct calculation of position. Ambiguity of measurements provided by differential systems should also be taken into account. The system design may have an adverse impact on air operations, and that is why alert limit ranges have been specified for precision approaches. Irrespective of that range value, the objective is to enable the optimal use of the satellite geometry when the characteristics of the monitor are acceptable from the perspective of positioning.

LPV-200 approaches have to fulfill many requirements which constitute a basis for verifying the compliance of the signal with the adopted standards. For the CAT I precision approach, the required accuracy is $16 \mathrm{~m}$ horizontally and 4-6 m vertically, integrity $1-2 * 10^{-7} / \mathrm{h}$, TTA $6 \mathrm{~s}$, continuity $1-8^{*} 10^{-6} / \mathrm{h}$, availability of 0.99 to 0.99999 , HAL $40 \mathrm{~m}$, and VAL 10-35 m [Aeronautical. Telecommunications, Annex 10, Vol. I, 2006]. Moreover, criteria are specified which are necessary to fulfill in order to maintain the acceptable level of safety for the visual flight segment. Accuracy without a malfunction is equivalent to ILS at locations where the operation is approved, and under all environmental conditions, i.e.:

- vertical navigation system error (NSE) (P95) less than $4 \mathrm{~m}$;

- vertical NSE exceeding $10 \mathrm{~m}$ with a probability of less than $10^{-7}$.

\section{STATIC MEASUREMENTS}

In order to check the performance of the GNSS signal in close proximity to the Dęblin airport, navigation solutions were registered before and after the dynamic measurement. Static measurements were performed using a JAVAD Delta-3 receiver. Delta-3 is a 864-channel, triple processor high-end receiver supporting GPS, Galileo, GLONASS, BeiDou, WAAS, EGNOS, and MSAS signal formats.

Recording with the intended frequency of $1 \mathrm{~Hz}$ was commenced on 25 February, 2016 at 23:03:02 UTC and finished on 3 March, 2016 at 10:33:54. Finally (after the elimination of gross errors and taking into account power interruptions), an analysis was started using 976,680 samples, which represented 98.47\% of the time interval in which the measurement was performed. Selection and analysis of the samples collected were conducted using the MATLAB software. 
ICAO recommends scaling the samples, by performing operations on a number of samples which will be statistically representative. In order to simulate the worst possible geometry, Annex 10 to the Chicago Convention in Appendix D recommends to calculate scaled navigational error as a product of the worst-case HDOP and the instantaneous NSE divided by the instantaneous HDOP. The following values were assumed for the purposes of this article and for scaling errors, in a horizontal plane HDOP $=2.5$, and in a vertical plane VDOP $=4.5$. Figure 1 shows the probability distribution of obtaining given error values for measured and scaled horizontal and vertical errors. The value of $95 \%$ marked with a red line corresponds to the level required by ICAO.
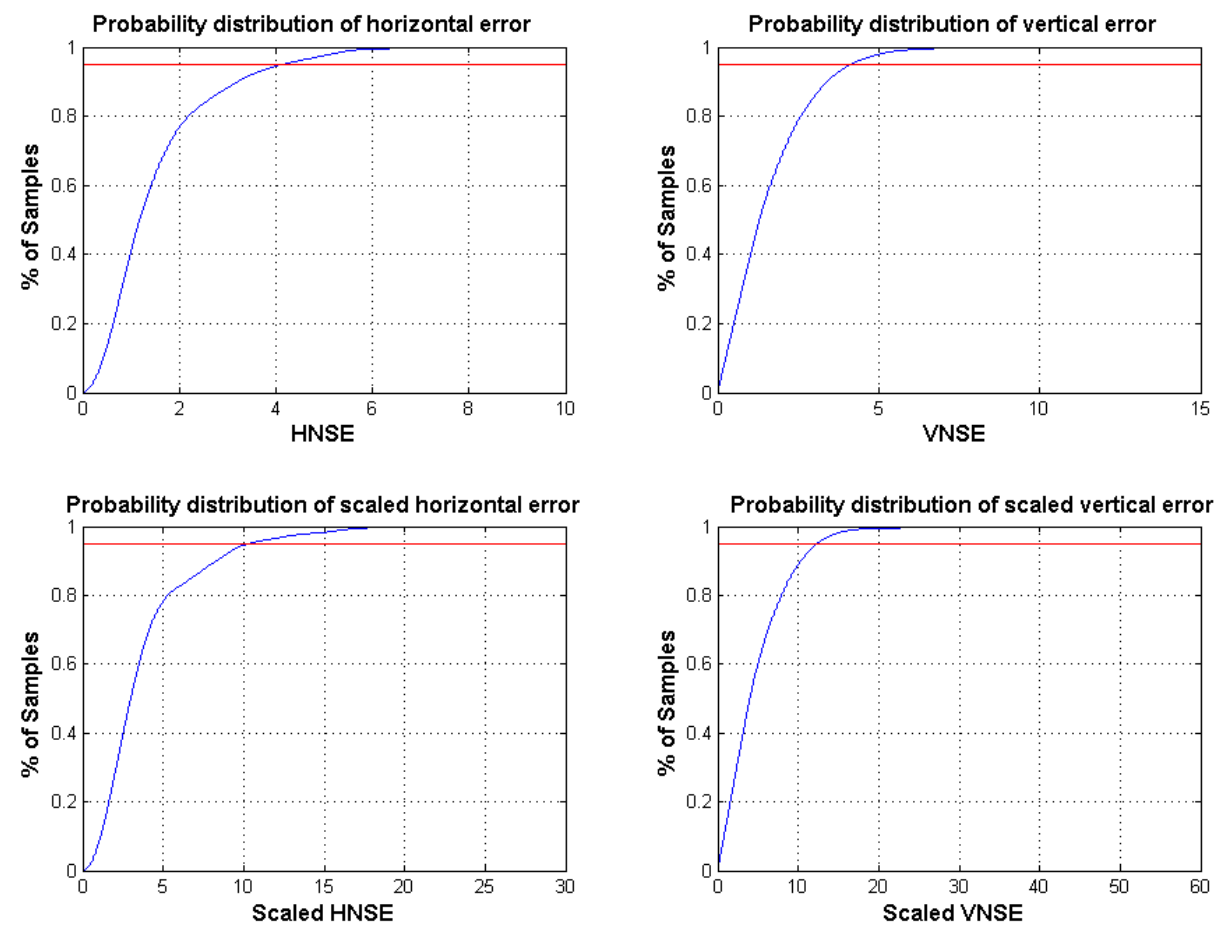

Fig. 1. Probability distribution of measured and scaled HNSE and VNSE

The error values measured leave a safety margin by depicting the $95 \%$ confidence level being equal to approx. $4.1 \mathrm{~m}$ for HNSE and VNSE. After scaling, the confidence level of $95 \%$ for the HNSE error value increases to approx. $10 \mathrm{~m}$ and falls within the range of the norm, but the VNSE error value exceeds $12.3 \mathrm{~m}$. 
It is worth mentioning that the value of HDOP during the measurements hardly exceeded the value of 2 , the average HDOP throughout the recording period amounted to 0.996 , which is a very good result, indicating excellent geometry parameters in terms of determining the position in the horizontal plane. What may be disturbing, however, is rapid increases of PDOP and VDOP, especially at night, between 3:00 and 4:00. On several occasions, VDOP exceeds 3.5, reaching even the value of 4 which is the general limit for professional applications, average VDOP $=1.48$.

Stanford diagrams for the geometry selected by the JAVAD receiver and the worst geometry (approximated by NSE scaling) were presented in Figure 2.
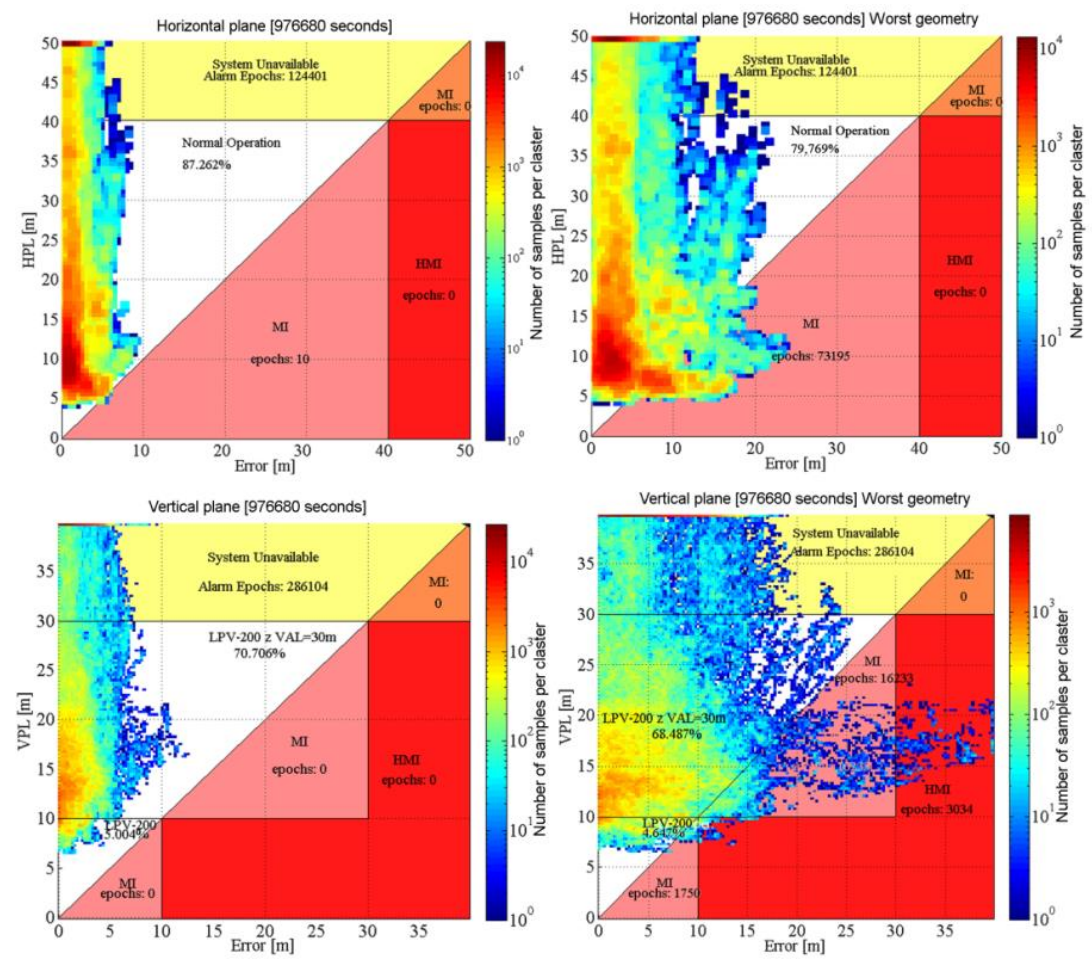

Fig. 2. Stanford diagrams for horizontal and vertical plane [www.waas.stanford.edu (access 15.02.2016)]

It is possible to quickly read that the signal does not meet the requirements of credibility even after excluding the samples where the system was unavailable from further considerations. This is because 10 samples on the graph for the horizontal 
plane generated MI - this is $1,02 * 10^{-5}$ percent of all samples, which exceeds the allowable norm. The graph for the vertical plane is much better as after the rejection of samples where the system was unavailable, the reliability would be $100 \%$. The total reliability for the recorded constellations is $70.71 \%$ assuming VAL $=30 \mathrm{~m}$, and $5 \%$ assuming VAL $=10 \mathrm{~m}$. The diagrams created for the worst geometry show that the system would be dangerous to use while generating significant amounts of MI, i.e. $7.45 \%$ of the samples for the horizontal and $1.84 \%$ of the samples for the vertical plane plus, additionally, $0.38 \%$ of HMI samples. These results are not satisfactory and even after the rejection of samples in which the system was unavailable the reliability requirements are not met. On the basis of the calculations based on ESSP report definitions, the risk of discontinuity was determined to be $1.25 \%$, and the calculated availability $73.25 \%$.

The recorded HAL and VAL values raise doubts as to the correctness of the data recorded, as they often exceed the level of $100 \mathrm{~m}$ and above. Protection levels recorded at the measuring station in Rzeszów did not reach such high values in the corresponding period of time. Local reasons or receiver calibration errors may be the reason for obtaining high Horizontal Protection Levels (HPL) and Vertical Protection Levels (VPL). For all samples recorded, the majority (75\%) has the HPL value of less than $25 \mathrm{~m}$, but $95 \%$ of them located within the $60 \mathrm{~m}$ limit. Corresponding VPL values are approx. $37 \mathrm{~m}$ and $87 \mathrm{~m}$. Taking into consideration the requirements of the ICAO these results are not satisfactory. When considering only those samples in which the LPV-200 was available, 95\% of the values is below $25 \mathrm{~m}$ for HPL and $30 \mathrm{~m}$ for VPL.

\section{CONCLUSIONS}

The research carried out at the airport in Dęblin constitute an important contribution to the analysis of the GNSS signal performance in eastern Poland. In terms of longitude, Dęblin Airport is situated only 8'24" west of the easternmost controlled airport in Poland, i.e. Rzeszów Jasionka. Examination of the quality parameters of GPS signal supplemented by the signal received from EGNOS satellites on the outskirts of the defined area in which EGNOS is fully efficient is the subject of many studies whose objective is to analyze and improve the efficiency of the system in these areas. Conducted research indicates that the signal recorded meets vertical and horizontal accuracy requirements as expressed by $95 \%$ 
probability. After scaling errors according to Annex 10 to the Chicago Convention, the system does not meet vertical accuracy requirements. Moreover, signal parameters do not meet the accuracy requirements for the visual approach (accuracy in the probability region of $10^{-7}$ - distribution tail), nor the requirements for integrity, continuity and availability. On the basis of additional calculations, for the time interval under consideration the risk of discontinuity was determined to be $1.25 \%$, and the calculated availability was $73.25 \%$.

The results obtained should be treated as preliminary measurements and a certain amount of skepticism ought to be maintained when analyzing them. The JAVAD receiver is a new product, which was installed one week prior to the measurements, and it is still subject to calibration. Furthermore, it should be kept in mind that the airport in Dęblin is a military facility. The operation of some military special-purpose systems may be the cause of the signal parameter quality decline. Identification of environmental causes of disrupting the operation of GNSS receivers, or affecting the signal itself, can contribute to significant improvements in the system performance and to the validation of APV, or even LPV-200, procedures.

\section{REFERENCES}

[1] Aeronautical. Telecommunications, Annex 10 to the Convention on International Civil Aviation, Volume I, Radio Navigation Aids, ICAO, 2006.

[2] Airline Losses May Top \$ 600 Million on Cancellations, [online], www.bloomberg.com [access 15.012016].

[3] AUGUR GPS RAIM Prediction Tool — GPS Status, [online], www.augur2.ecacnav.com [access 06.03.2016].

[4] Flight delays cost $\$ 32.9$ billion, passengers foot half the bill, [online], www.news.berkeley.edu [access 15.01.2016].

[5] Military AIP Poland, PANSA, Warsaw 2013.

[6] The board of trustees of the Leland Stanford Junior University, 1998, [online], www.waas.stanford.edu [access 15.02.2016].

[7] www.egnos.org.pl [access 06.03.2016].

[8] www.eurocontrol.int [access 15.02.2016].

Received September 2016

Reviewed December 2016 


\section{MAREK GRZEGORZEWSKI}

Polish Airforce Academy

35 Dywizjonu 303 Str., 08-521 Dęblin, Poland

e-mail: marekgrzegorzewski@wp.pl

\section{KAROL KRZYSZTOF ŚLIWAK}

Polish Airforce Academy

35 Dywizjonu 303 Str., 08-521 Dęblin, Poland

e-mail:karol.sliwak@gmail.com

\section{STRESZCZENIE}

Obecne procedury podejść do lądowania RNAV GNSS znajdują szerokie zastosowanie w Europie i na świecie. Dzięki rozwojowi systemów GNSS, a także analizie i kontroli sygnałów satelitarnych liczba podejść GNSS stale rośnie. Możliwe staje się projektowanie podejść do lądowania z coraz większymi wymogami co do parametrów sygnału z jednocześnie niższymi minimami. LPV-200 jest skrótem oznaczającym precyzyjne podejście do lądowania o najwyższych wymogach i minimum operacyjnym do $200 \mathrm{ft}$. Na potrzeby pierwszej części artykułu zostały przeprowadzone pomiary statyczne sygnału GNSS w celu porównania ich $\mathrm{z}$ wymaganiami stawianymi przez ICAO. Zasadniczo na podstawie przeprowadzonych pomiarów można stwierdzić, że w analizowanym okresie sygnał GNSS spełniał jedynie częściowo wymogi stawione podejściom LPV-200. Zgromadzone dane zostały przetworzone i przeanalizowane w środowisku Matlab. 